\title{
The Devil's Tabernacle: The Pagan Oracles in Early Modern Thought
}

Review Number: 1685

Publish date: Thursday, 6 November, 2014

Author: Anthony Ossa-Richardson

ISBN: 9780691157115

Date of Publication: 2013

Price: $£ 22.00$

Pages: 360pp.

Publisher: Princeton University Press

Publisher url: http://press.princeton.edu/titles/10019.html

Place of Publication: Princeton, NJ

Reviewer: Justin Champion

Demons or cunning priests?

'The Pythia at Delphi, sitting with her petticoats bunched up and her arse on the Tripod, received her inspiration from below'. Denis Diderot

This is a welcome, learned and well-crafted work, which establishes an important perspective across European encounters with, and attitudes towards, the nature, significance and authenticity of the pagan oracles between the Renaissance and the early Enlightenment. It draws upon a deep well of erudition, and is written with admirable clarity and style. The focus of the book is a consideration of how the cultural history of the Delphic oracle, and its supposed silencing at the coming of Christ, was inflected by developments in erudition, the dynamic of confessional dispute and the transformation of systems of public communication.

Although aware of the debates about the material culture of ancient examples, especially of the Delphic oracle, Ossa-Richardson's ambition is to explore and engage with the burgeoning textual traditions, and to explore the cultural and imaginative work those writings undertook for authors and readers. The book's ambition is to outline and describe how an account of the oracles not only underpinned the Renaissance reconstruction of the nature of pagan religion, but also provided context for debates about the nature of, for example, witchcraft, as ammunition in the confessional and sectarian wars of ideas. The various accounts of the oracles became a weapon of inter-confessional dispute and eventually a contributory stream to the development of heterodox and freethinking critiques of organised religion, although this was not as straightforward as is often claimed. Were the outpourings of the Oracles mere imposture, the work of the Devil, a fatal combination of the two, or the manifestation of natural material phenomena? The book explores not only the increasing sophistication of the recovery of the material history of the ancient practices, but also how embedded these discoveries were in the context of a transforming intellectual and theological political world.

The book, draws from the traditions of enquiry identified most profoundly with the intellectual legacy associated with the Warburg Institute, and specifically of historians like D.P. Walker and more recently 
Anthony Grafton, whose powerful studies on the Renaissance and post-humanist encounters with the literature of Antiquity and the patristic canon formed the bedrock of accounts of the nature of heathen religious institutions and belief, and subsequent relationships with the evolution of Christian tradition.(1) The book then, is as much an examination of the development of practices of erudition, establishing how rival and contested accounts of the classical and early Christian texts were exploited and appropriated for specific local purpose. That the pagan oracles were destroyed by Christ, and that they represented a model of bad and failed religion, was with some variation a commonplace extracted from the early sources like Eusebius, Tertullian and Cicero. By the start of the 17th century such representations of figures like Pythia became anchored to the polemics and debates provoked by the rise of a more profound and sophisticated Christian demonology. The Oracle Pythia became an 'other' to the godly prophet. As a confessional war between Catholic and Protestant understandings of possession, witchcraft and magic became both more entrenched and fundamentalist, making meaning from the evidence of the ancient example became more important. Divine prophecy was carefully demarcated from demonic divination. Importantly though, preserving the reality of diabolical activity was essential to preserving the 'truth' of Christianity; without the defeat of the Devil, or lesser demons, there might be no Christian triumph. Wonders and miracles might be imitated by the Devil so well as to pervert believers into distraction; it was the duty of the godly minister to expose such as the vain aping of God. Later in the 17th century, the need to disable the claims of the false prophets of the Popish churchencouraged Protestant polemicist to deploy similar arguments for the continuity of deceitful conduct by their contemporaries. What may have appeared as detailed debates about the interpretation of ancient texts was more than simply erudition but an aspect of a powerful debate about the nature of the pastoral authority and power of contemporary ecclesiastic institutions and people.

If the view that Pythia's oracles had been inspired by the Devil, and his minions, but destroyed by Christ's coming, was dominant throughout the 16th and 17th centuries, it was also increasingly unpicked as the rival explanatory claims of the (priestly) fraudulent manipulation of natural circumstances. As Thomas Browne noted succinctly 'Men looked upon ancient oracles as natural, artificial, demoniacal, or all'. Explored and analysed in precise and elegant detail here, libertin and heterodox authors like Pomponazzi, Fontenelle, and Bekker (amongst the more notorious) exploited their accounts to represent the oracles as evidence of the continuity of religious fraud and imposture. The impact of confessional dispute also saw the widening of the audience for such debates - erudition was made public, in the vernaculars of Dutch, English and French, and not simply the vast Latin folios of the universities. At some point the Protestant critique of Catholic priestcraft evolved into a powerful indictment of clerical imposture tout court. The Radical Enlightenment appropriation of anti-popish accounts of techniques of oracular fraud to a more profound denial of the existence of divine activity in the world found its most public and controversial expression in the work of Dutchman Antony Van Dale of the early 1680s, and subsequently that of Bernard de la Fontenelle in France. Here the imposture of the oracles acted as a means to contrast the superstitious and corrupt world of religion with the possibilities of a rational worldview.

Ossa-Richardson has written an important book, which should be the first port of call for any historian of ideas, of religion and of learning to explore. There is a deep learning on display, and the footnotes deliver some wonderful seams of scholarship to explore. The overarching anti-teleological argument of the book is subtle, and in underscoring the changing emphases and uses of the textual tradition and its significance, it cautions against a trajectory of explanation which saw intellectual culture 'progress' from superstition to enlightenment. It may be unfair to ask for more from such an impressive marshalling of sources, ideas and contexts from across Europe, but a number of questions arise, which might strengthen or focus some of the arguments. First, an impressive community of authors is examined, and very often the textual relationship between the expression of ideas is the primary means of establishing links or even influences. The crossconfessional transactions and disputes are explored with confidence. Adding a dimension of what has become fashionably known as 'book history', might offer further illumination. Much of the later engagement involved editions, translations and reception - perhaps mapping out the key moments in these developments would be useful (admittedly this would have probably been resisted by the publisher's constraints on space). There are distinguished and canonical figures who rub alongside some more obscure (but nevertheless 
erudite) contributors: establishing the intimacies between some of this European wide community of scholars, along the lines of Goldgar's work on the later republic of letters, or Brockliss on Calvet's Web might again underscore some further aspects. (2)

One of the other questions that the book prompted was how does the textual encounter with the oracles connect to the developing practices of erudition associated with both Biblical criticism and patristic scholarship? The work of Jean-Louis Quantin on the confessional disputes and communities of, in particular, patristic learning might provide a context for thinking about how the practice of erudition provided trustworthy authority for pressing contextual debates about the status of churchmen, or doctrinal dispute. (3)

As the book is very effective at establishing, very often specific debates were prompted, not simply by the historical issue, but by a concern to comment, adjudicate, challenge the understanding of a local contemporary event. The many works were the product not simply of university men, but what the book terms 'professional theologians'. How, by writing about ancient oracles, clergymen and their opponents were defending or compromising the social status and power of their rivals lies at the root of much of the material here. That those exchanges and polemics were eventually played out in a wider public sphere is apparent in one of the texts Ossa-Richardson mentions briefly (p. 256) - The Delphick Oracle (1720). Here members of the public had posed to the 'learned' a series of questions of theological, historical and political concern, and the findings of a European wide community of scholars was abridged and fashioned for a coffee-house audience in a reasonably cheap print form. Making meaning out of the example of the oracles by the early 18th century, at least in England, was not simply an act of erudition or the professional theologian, but of the journalist and the entrepreneurial publisher.

These are not criticisms, but a means of noting the depth of research and impressive command of a wide chronological and variety of national scholarships on the subject. Ossa-Richardson's book should become a foundational work for exploring the changing shape of the relationship between erudition and cultural change, as well as for understanding the changing perceptions of the history of religion, and by consequence the development of a critique of contemporary religions, which has explored in some measure most recently in the work of J. G. A. Pocock in his multi-volume magnum opus on Gibbon, and in Jan Assmann's explorations of the representation of Moses. (4)

\section{Notes}

1. For example see D. P. Walker, Spiritual and Demonic Magic: From Ficino to Campanella (London, 1958), see also The Decline of Hell: Seventeenth-Century Discussions of Eternal Torment (Chicago, IL, 1964), and Unclean Spirits: Possession and Exorcism in France and England in the Late Sixteenth and Early Seventeenth Centuries (Philadelphia, PA, 1981). For Grafton see in particular Anthony Grafton,Forgers and Critics. Creativity and Duplicity in Western Scholarship (Princeton, NJ, 1990); Defenders of the Text: The Traditions of Scholarship in the Age of Science, 1450-1800 (Cambridge, 1991); Commerce with the Classics: Ancient Books and Renaissance Readers (Ann Arbor, MI, 1997); The Footnote: A Curious History (Cambridge, 1997).Back to (1)

2. See A. Goldgar, Impolite Learning: Conduct and Community in the Republic of Letters, 1680-1750 (New Haven, CT, 1995); L. W. B. Brockliss, Calvet's Web: Enlightenment and the Republic of Letters in Eighteenth-century France (Oxford, 2002). Back to (2)

3. Jean-Louis Quantin, Le catholicisme classique et les Pères de l'Église. Un retour aux sources (1669-1713) (Paris, 1999) and The Church of England and Christian Antiquity: The Construction of a Confessional Identity in the 17th Century (Oxford, 2009).Back to (3)

4. See J. Assmann, Moses the Egyptian: The Memory of Egypt in Western Monotheism (Harvard, 1997); idem, Religio Duplex: How the Enlightenment Reinvented Egyptian Religion (London, 2014); J. G. A. Pocock's project on Barbarism and Religion, is currently in six volumes, (Cambridge, 1999-2014). Back to (4) 
Source URL:https://reviews.history.ac.uk/review/1685

\section{Links}

[1] https://reviews.history.ac.uk/item/59285 